\title{
PEMBINAAN ETIKA SOPAN SANTUN PESERTA DIDIK KELAS V MELALUI PEMBELAJARAN PENDIDIKAN KEWARGANEGARAAN DI SEKOLAH DASAR NOMOR 45 KOTA BENGKULU
}

\author{
Puspa Djuwita \\ Pendidikan Guru Sekolah Dasar \\ Fakultas Keguruan dan Ilmu Pendidikan, Universitas Bengkulu
}

\begin{abstract}
Abstrak
Tujuan penelitian adalah memotret pembinaan etika sopan santun pada peserta didik dalam pembelajaran PKn di kelas V SD Negeri 45 Kota Bengkulu, sejak dari guru mendesain pembelajaran, melaksanakan pembelajaran $\mathrm{PKn}$, mengevaluasi perilaku sopan santun peserta didik, serta respon peserta didik terhadap pembinaan sopan santun yang dilakukan guru melalui pembelajaran PKn. Penelitian ini menggunakan metode deskriptif kualitatif, teknik pengumpulan data menggunakan teknik observasi, wawancara secara mendalam dan dokumentasi (artipak). Obyek penelitian adalah kegiatan pembelajaran PKn yang sedang berlangsung. Subyek penelian adalah guru kelas, teman sejawad dan kepala sekolah. Instrumen pengumpulan data adalah peneliti sendiri dengan bantuan pedoman observasi dan pedoman wawancara. Data dianalisis secara narasi dengan pemaknaan secara mendalam. Simpulan dari hasil penelitian mengindikasikan (1) desain pembelajaran PKn yang dibuat oleh guru menggunakan silabus BNSP. Guru tidak menganalisis SK dan KD terlebih dahulu. RPP yang dipakai bersumber dari buku pegangan atau panduan guru tanpa analisis misi nilai dan perilaku yang diharapkan dari SK dan KD, sehingga indikator yang dirumuskan tidak terdapat pembinaan etika sopan santun yang akan dilakukan. Materi tidak dikembangkan secara kontekstual; (2) ketika pembelajaran dilaksanakan guru telah melakukan pembinaan perilaku sopan santun. Gurutelah mampu memotivasi peserta didik untuk berperilaku sopan santun; (3) evaluasi hasil pembinaan perilaku sopan santun belum terprogram secara formal, evaluasi masih dominaan pada evaluasi aspek kognitif, (4) peserta didik telah merespon secara positif dan aktif terhadap membinaan perilaku sopan santun .
\end{abstract}

Kata kunci: PKn, pembinaan, sopan santun.

\section{PENDAHULUAN}

Sekolah sebagai kepanjangan tangan pemerintah untuk mencapai tujuan pendidikan nasional wajib melaksanakan amanah UndangUndang Sistem Pendidikan Nasional (UU Sisdiknas) Nomor 20 Tahun 2003, yang menghendaki penyelenggaraan pendidikan di Sekolah Dasar (SD), berfungsi memberikan bekal dasar, pengembangan kemapuan pikir, keterampilan, dan karakter peserta didik untuk kehidupan masa depannya. Baik kehidupan pribadi maupun masyarakatnya. Institusi ini juga mempersiapkan peserta didik untuk mengikuti pendidikan ketingkat selanjutnya.Dengan demikian pendidikan yang diselenggarakan di SD tidak hanya bertujuan untuk mengembangkan kemampuan peserta didik dalam ilmu pengetahuan, kecakapan dan kreativitas saja tetapi juga berkewajiban membina peserta didi menjadi manusia yang beriman dan bertakwa kepada Tuhan Yang Maha Esa, berakhlak mulia, mandiri, warga Negara yang demokratis, bertanggung jawab atas perbuatan yang dilakukannya.Untuk mendukung itu di SD peserta didik diwariskan nilai-nilai budaya masyarakatnya, agar mereka tidak kehilangan jati diri sebagai bangsa Indonesia.

Sebagai pendidik di sekolah, guru memiliki tanggung jawab secara moral untuk mengarahkan dan membantu peserta didik berperilaku baik,melindungi mereka dari hal-hal yang akan merusak kepribadiannya. Dibawah bimbingan guru, peserta didik dibimbing tata 
cara bersosialisasi sesuai dengan norma, moral dan etika masyarakat di mana ia hidup.Amanah ini hendaknya dipegang teguh dan dijalankan dengan sepenuh hati oleh para pendidik di sekolah. Ini dikarenakan peserta didik di SD merupakan tanggung jawab guru untuk diarahkan pada hal-hal kebaikan, mengingat pada usia ini peserta didik sedang mengalami perkembangan yang saat peka terhadap pengaruh-pengaruh dari lingkungan.

Mencermati fenomena perilaku warga negara saat ini, banyak kita lihat perilakuperilaku yang tidak beretika yang ditunjukan oleh pemuda dan anak remaja. Perilaku itu seperti melanggar etika di jalan raya, tidak peduli dengan lingkungan sosial, mengucapkan katakata yang tidak pantas pada orang yang lebih tua, berkata-kata kasar pada sesama teman, membantah pada orang tua, guru dan pendidik.Pelanggaran-pelanggaran etika sopan santun seperti ini, dipandang sebagai perwujudan rendahnya sikap sopan santun para pemuda dan anak remaja. Untuk itulah guru hendaknya tidak bosan membinakan etika sopan santu pada peserta didi melalui proses pembelajaran terutama melalui pembelajaran Pendidikan Kewarganegara (PKn). Sebagaimana diketahui pembelajaran PKn bertujuan membentuk karakter atau watak yang baik bagi peserta didik, dan membantu mereka menjadi warganegara yang mampu:(a) berpikir kritis, rasional, dan kreatif; (b) berpartisipasi secara aktif dan bertanggung jawab; (c) berkembang secara positif(Susanto, 2013: 231). Selain itu PKn di sekolah dikembangkan sebagai pusat pengembangan wawasan, sikap, dan keterampilan hidup dan berkehidupan demokratis agar terbangun kehidupan demokrasi. Winataputra (2009: 17). Kehidupan demokrasi yang dikehendaki itu wajib didasari oleh perilaku yang:(1) beriman kepada Tuhan Yang Maha Esa dan menghayati nilai-nilai falsafah bangsa; (2) berbudi pekerti luhur, berdisiplin dalam bermasyarakat, berbangsa dan bernegara; (3) rasional; (4) aktif memanfaatkan ilmu pengetahuan (Sumarsono, 2008: 6). Oleh karena itu, yang perlu mendapat perhatian seorang guru dalam melaksanakan pembelajaran di kelas, hendaknyanya guru memilik berbagai pengetahuan dan wawasan yang luas dalam rangka mendukung pengembangan materi pelajaran.

Guru wajib memahami dengan baik visi, misi dan tujuan pembelajaran PKn, memahami konsep-konsep yang akan membantunya untuk membinakan perilaku etika sopan santun, seperti konsep tentang nilai, moral, dan etika, konsep tentang berbagai pendekatan, model pendidikan nilai, dan model pembelajaran lainnya, serta media pembelajaran yang akan mendukung proses pembinaan etika sopan santun. Dengan demikian guru dapat memanfaatkan multi disiplin ilmu, multi metode, danmulti media agar dapat melaksanakan pembelajaran PKn dalam rangka mencapai tujuan yang diharapkan. Sebab melalui pembelajaran PKndiharapkan peserta didik memiliki etika sopan santun yang baik serta sikap dan perilaku yang mencerminkan manusia Indonesia yang memiliki nilai-nilai yang terdapat dalam rumusan Pancasila dan bertanggung jawab terhadap segala perilakunya. Oleh karena itu pada kegiatan pembelajaran di kelas guru dituntut berperan penuh dan tanggung jawab dalam memberikan pendidikan sopan santun melalui pembelajaran PKn.Agar dapat melaksanakan tugas itu dengan baik dan tepat guna, maka guru harus mengembangkan materi atau menyediakan sumber belajar yang memuat secara tersurat tentang etika sopan santu dalam materi PKn

Sopan santun ialah suatu tingkah laku yang amat populer dan nilai yang natural. Sopan santun yang dimaksud adalah suatu sikap atau tingkah laku individu yang menghormati serta ramah terhadap orang yang sedang berinteraksi dengannya. Sopan santun menurut Antoro (2010:3) sebagaiperilaku individu yang menjunjung tinggi nilai-nilai menghormati, menghargai, tidak sombong dan berakhlak mulia.Perwujudan dari sikap sopan santun ini adalah perilaku yang menghormati orang lain melalui komunikasi yang menggunakan bahasa yang tidak meremehkan atau merendahkan orang lain. Sopan santun secara umum adalah peraturan hidup yang timbul dari hasil pergaulan dalam kelompok sosial. Norma kesopanan bersifat 
relatif, artinya apa yang dianggap sebagai norma kesopanan akan berbeda-beda di berbagai tempat, lingkungan, dan waktu.

Menurut kamus bahasa Indonesia, sopan berarti hormat dengan tak lazim secara tertib menurut adab yang baik. Sedangkan santun adalah halus dan baik (budi bahasanya, tingkah lakunya). Jika kedua kalimat itu digabungkan, maka sopan santun adalah pengetahuan yang berhubungan dengan penghormatan melalui sikap, perbuatan atau tingkah laku.

Peserta didik SD berada pada usia pertumbuhan yang sangat peka.Mereka umumnya sangat senang bergerak, bermain, berbicara, dan sulit diajak diam. Akan tetapi mereka memiliki tingkat kepercayaan yang tinggi kepada gurunya. Terhadap kondisi ini guru dapat menjadi model dalam membina dan medidik sopan santun pada peserta didik di sekolah.Gurudapat memanfaatkan kepercayaan peserta didik tersebut kepadanya. Pada kondisi ini pembinaan perilaku sopan santun perlu menjadi perhatian serius guru dalammendidikan dasar-dasar perilaku sopan santun. Sebagai pendidik guru dapatmenjadi modek dalam memberikan contoh riil bagaimana berperilaku sopan santun.

Permasalahan dalam kajian ini adalah bagaimana guru membina etika sopan santun dalam proses pembelajaran PKn pada peserta didik kelas V SD Negeri 45 Kota Bengkulu. Permasalahan ini dirumusankan lebih rinci sebagai berikut:(1) bagaimanakah cara guru mendesain pembelajaran PKn yang bermuatan pembinaan etika sopan santun di kelas V SD Negeri 45 Kota Bengkulu; (2)bagaimana gurumelaksanakan pembelajaran PKn yang bermuatan pembinaan etika sopan santun di kelas V SD 45 Kota Bengkulu; (3) bagaimana cara guru mengevaluasi perilaku sopan santun peserta didik dalam pembelajaran PKn di kelas V SD 45 Kota Bengkulu; (4) bagaimana respon peserta didik kelas V SD 45 Kota Bengkulu terhadap pembinaan etika sopan santun dalam proses pembelajaran PKn.

Tujuan dilaksanakannyapenelitian adalah ingin memotret pembinaan etika sopan santun yang dilakukan oleh guru pada peserta didik dalam pembelajaran PKn di kelas V SD Negeri 45 Kota Bengkulu, mulai dari guru mendesain pembelajaran, melaksanakan pembelajaran yang membina etika sopan santun, mengevaluasi perilaku sopan santun peserta didik, serta respon mereka terhadap pembinaan sopan santun yang dilakukan guru melalui pembelajaran PKn. Adapun manfaat yang diharapkan dari kegiatan penelitian ini adalah(1) berkembangnya wawasan tentang pembelajaran $\mathrm{PKn}$ bermuatan nilai moral,(2) diperolehnya pengalaman lapangan tentang kondisi riil pembelajaran $\mathrm{PKn}$, (3) adanya pembaharuan dalam pembelajaran $\mathrm{PKn}$

\section{METODE}

Penelitian ini menggunakan metode deskriptif kualitatif, metode ini digunakan untuk mendapatkan gambaran yang lengkap dan utuh tentang pembinaan perilaku sopan santun pada peserta didik melalui pembelajaran PKn di kelas V SD 45 Kota Bengkulu sesuai dengan keadaan riil di lapangan. Teknik pengumpulan data menggunakan teknik observasi, wawancara secara mendalam dan dokumentasi. Obyek penelitian adalah kegiatan pembelajaran PKn yang sedang berlangsung. Subyek penelian adalah guru kelas, teman sejawat dan kepala sekolah. Instrumen pengumpulan data berupa pedoman observasi dan pedoman wawancara yang telah dibuat sebelum terjun ke lapangan (SD kelas V). Analisis data dilakukan saat di lapangan dan sesudah di lapangan. Data dianalisis secara narasi dengan pemaknaan secara mendalam

\section{HASIL}

Desain pembelajaran yang buat ke dua orang guru kelas $\mathrm{V}$, mulai dari merancang silabus, yang memuat komponen-komponen identitas mata pelajaranStandar Konpetensi (SK), Kompetensi Dasar (KD), materi pembelajaran, kegiatan pembelajaran, indikator pencapaian kompetensi, penilaianyang terdiri dari jenis tagihan, bentuk instrumen dan contoh instrumen, 
alokasi waktu dan sumber/bahan/alat belajar, pengalaman belajar, karakter yang diharapkan, pada kolom ini tidak terdapataspekperilaku sopan santun didalamnya. Ini berdasarkan penyataan kedua guru bahwa perilaku sopan santun tidak tercantum dalam silabus.

Dari silabus ini kedua guru mengembangkan Rencana Program Pembelajaran (RPP). Dalam RPP yang dibuat guru memuat secara lengkap komponen RPP yang baku. SK yang tercantum SK 4, menghargai keputusan bersama dan pada KD 4.1 mengenal bentuk-bentuk keputusan bersama. Materi pembelajaran yang tercantum dalam RPP pada pertemuan pertama adalah bentuk-bentuk kepusan bersama, pertemuan kedua menerima dan mematuhi keputusan bersama, pada pertemuan ke tiga menerima dan mematuhi keputusan bersama. Dari SK dan KD guru merunuskan indikator dan tujuan pembelajaran. Dalam indilator dan tujuan pembelajaran tidak tercantum pembinaan sopan santu. Dari wawancara guru menyatakan bahwa tidak dicantumkannya sopan santu baik di silabus maupun pada RPP dikarenakan sopan santun itu tidak tercantum dalam SK KD. Kegiatan pembinaan sopan santu dilakukan secara insidental saja. Namun beliau memasukkan pembinaan sopan santun itu ke dalam langkahlangkah pembelajaran.

Sekolah ini menggunakan Kurikulum Tingkat Satuan Pendidikan (KTSP), guru menggunakan silabus berdasarkan kurikulum KTSP, pengembangan RPP dari buku pegangan/panduan, mengacu pada pengalaman belajar yang tertera dalam silabus. Guru membagi KD untuk dua kali pertemuan, RPP dibuat untuk dua kali pertemuan dengan alokasi waktu 2 × 35 menit untuk setiap pertemuannya.

Indikator pencapaian kompetensi yang dibuat hampir serupapada kedua guru tersebut, tujuan pembelajaran yang dirumuskan secara umum dominan pada aspek pengetahuan, aspek sikap masih terdapat.Namun pada RPP tercantum perilaku yang diharapkan untuk menjadi karakter peserta didik yaitu jujur, penghormatan, perhatian, tekun, tanggung jawab, berani, integritas, peduli, jujur.
Pengembangan materi dilakukan berdasarkan dari buku pegangan guru dan dari penelusuran di internet. Pendekatan dan metode pembelajaran adalah pendekatan konstruktivisme, diskusi dengan teman sebangku, diskusi kelompok, ceramah, tanya jawab, dan penugasan. Langkah-langkah kegiatan pada RPP dimulai dari kegiatan awal yang terbagi menjadi apersepsi (motivasi).Kegiataninti terbagi menjadi eksplorasi, elaborasi dan konfirmasi serta kegiatan penutup. Pada kegiatan eksplorasi di RPP, guru melibatkan siswa aktif dalam kegaitan pembelajaran, tanya jawab dan kajian materi. Pada kegiatan elaborasi, peran guru sesuai dengan standar proses yag dibuat oleh BSNP. Kegiatan eksplorasi dalam RPP mengarah pada aspek pengetahuan. Kegiatan penutup pada RPP guru bersama siswa mesimpulkan atau rangkuman pembelajaran, diakhiri dengan pesan moral.

Media digunakan adalah gambar tentang bentuk-bentuk keputusan bersama sedangkan sumber belajar yang tertera pada RPP adalah buku paket PKn untuk SD kelas V, selain itu orang tua, teman, lingkungan rumah (keluarga), sekolah juga menjadi sumber. Penilaian digunakan penilaian sikap, penilaian ini dibuat dalam bentut format dan kriteria penilaiannya terbagi menjadi produk dan performansi. Pada kriteria produk (dari hasil diskusi), guru menggunakan aspek konsep dengan kriteria semua benar skor 4, sebagian besar benar skor 3, sebagian kecil benar skor 2 dan semua salah dengan skor 1. Pada performansi, terdapat aspek pengetahuan dengan kriteria pengetahuan skor 4 , kadang-kadang pengetahuan skor 2, bukan pengetahuan skor 1. Untuk aspek sikap,sering nampak skor 4, kadang-kadang skor 2, dan tidak nampak skor 1 . Teknik dan instrumen penilaian sikap yang dicantumkan di RPP, dengan cara guru mengamati perilaku peserta didik ketika mereka berdiskusi bersama.

Setiap kali pertemuan selalu diawali mengucapakan salam antara guru dan sisiwa diawal pembelajaran guru memulainya dengan melakukan apersepsi, dan memotivasi siswa setelah itu guru menyampaikan materi 
pembelajaran tentang bentuk-bentuk keputusan bersama. Dilanjutkan dengan tanyajawab, setelah itu guru mengajak siswa untuk membentuk kelompok dengan membagi dua setiap barisan siswa, dan memberi pengarahan apa tugas yang akan dilakukan peserta didik. Guru membagikan LDS dan membuka media gambar, peserta didik diminta untuk mendiskusikan apa maksud gambar tersebut. Selama peserta didik bekerja dalam kelompok, guru mengamatiperilakupeserta didik, selama diskusi berjalan guru mengingatkan pada peserta didik untuk saling menghormati dan mengharga pendapat kawan, tidak membeda-bedakan antara sesama teman dalam kelompok, bermusyawarah dalam kelompok, tidak medominasi dan memaksakan pendapat sendiri pada teman. Peserta didik tetap bekerja sambil mendengarkan saran guru.

Di sela diskusi, sempat ada peserta didik yang bertahan dengan pendapatnya sendiri namun kemudian mereka sepakat untuk mencari jalan tengah dengan melihat kembali penjelasan dari buku pelajarannya. Selama kegiatan diskusi kelompok, guru selalu ada diantara mereka memberi motivasi, membimbing pada yang memerlukan. Hasil diskusi kelompok dipresntasikan oleh masing-masing kelompok melalui perwakilannya. Setelah kegiatan ini guru mengulas kembali hasil diskusi mereka. Terlihat dipojok kelas ada kelompok yang berdiskusi sendiri tanpa mengindahkan penjelasan guru. Terhadap perilaku ini guru menegur agar mereka memperhatikan penjelasan dulu baru setelah itu boleh diskusi.

Setelah semua hasil diskusi dibahas, guru membagikan soal evaluasi.Sementara peserta didik mengerjakan soal evaluasi, guru memberi penilaian hasil kerja kelompok. Pada saat pengumpulan tugas evaluasi terlihat peserta didik saling dorong untuk mengumpulkannya, guru menemangkan mereka supaya antri dan menghormati teman yang lebih dulu.Sebelum mengakiri pembelajaran, guru bertanya, "apa saja bentuk-bentuk keputusan bersama, setelah dijawab oleh peserta didik, guru melanjutkan, jika suatu keputusan telah ditetapkan melalui musyawarah bagaimana sikap kita kita?"“Jika kita sepakat kita akan menerima dengan senang hati pak". Mendengar jawaban tersebut guru tersenyum, dan berkata "ya betul bagus sekali cindy. Beri tepuk tangan untuk cindy. Baiklah pada pertemuan berikut kita akan mepelajari menerima keputusan bersama, sekarang kalian boleh beristirahat".

Dari beberapa kali pertemuan, kegiatan pembelajaran berjalan sebagaimana tersebut di atas, guru memimpin kelas, jika terjadi pelanggaran perilaku guru langsung menegur, memberi penghormatan dan penghargaan jika peserta didik menunjukkan perstasinya, baik prestasi dalam kemampuan akademik maupun kemamuan perubahan perilaku pada saat kegiatan pembelajaran. Selama pelaksanaan pembelajaran, terlihat guru mencontohkan berperilaku sopan santun dengan mendengarkan dan menghargai pendapat peserta didik . jika ada peserta didik saling mengejek, guru akan mengatakan tidak baik mengejek teman, itu mananya tidak sopan dan perilaku yang tidak terpuji. Cara lain yang dilakukan guru dalam membina perilaku sopan santun, dia mengatakan dalam mematuhi keputusan bersama, kita hendaknya menunjukkan perilaku sopan saat membuat keputusan, rukun, tidak ribut apalagi berkelahi dalam mengambil keputusan bersama. Disamping ituguru mengarahkan siswa agar menghormati temannya yang sedang berbicara baik itu mengutarakan pendapat maupun penyajian hasil diskusi kelompok dengan mendengarkan terlebih dahulu baru kemudian kalian boleh menyanggah atau menambahkan. Guru juga membina peserta didik menghormati orang lain yang ditunjukkan dengan mendatangi seorang peserta didik yang memukul meja dan mengatakan tidak boleh melakukan itu.

Penilaian perilaku sopan santun dilakukan guru selama kegiatan pemebelajaran melalui pengamatan terhadap setiap perilaku yang ditunjukkan peserta didik. Instrumennya berupa kriteria, kadang-kadang dan belum. Namun catan perilaku ini tidak selalu dibut guru hanya jika perilaku itu terlalu sering muncul baru guru membuat catatan khusus. 
Respon peserta didikdalam kegiatan pembelajaran PKn yang bermuatan pembinaan perilaku sopan santun ini; guru memotivasi peserta didik untuk berperilaku sopan santun dengan cara mengemukakan peristiwa sehari-hari kegiatan manusia yang menunjukkan perilaku sopan santun. Guru mengajak peserta didik untuk beperilaku sopan santun dan menunjukkan bagaiman tata cara berperilaku sopan santun dalam kegiatan sehari-hari. Pada kegiatan ini peserta didik mendengarkan apa yang diungkapkan guru. Kadang kala diselingi oleh beberapa peserta didik bertanya tentang etika sopan santun. Respon peserta didik terhadap etika sopan santu yang dikehendaki guru itu cukup positif, ini mereka tunjukan dengan menerapkan sopan santun yang diajarkan oleh guru. Respon ini ditunjukan seperti, meminta izin saat ingin keluar, mengangkat tangan ketika akan menyampaikan pendapat, tidak serta merta menyela pembicaan teman ketika temannya sedang mengemukakan pendapat, tidak mengejek teman ketiga menjawab pertanyaan dan jawabannya belum tepat.

\section{PEMBAHASAN}

Desain Pembelajaran PKn yang dibuat guru sudah memenuhi kriteria standar dalam pembuatan silabus, demikian pula ketika mengembangkan silabus ke dalam RPP. Namun guru tidak menganalisis terlebih dahulu nilainilai dan atau perilaku yang tersirat yang akan dibinakan dalam SK, KD dalam kurikulum, hal inilah yang menyebabkan pembinaan perilaku sopan santun tidak dirumuskan secara jelas dalam silabus dan RPP. Pembinaan perilaku dan atau nilai sopan santun yang tersirat itu seharusnya mampu ditangkap dan dimaknai dengan guru merumuskannya dalam indikator seta tujuan pembelajaran dalam RPP. Guru menyadari bahwa dalam pembelajaran PKn wajib dibinakan perilaku-perilaku yang sesuai dengan nilai-nilai dalam rumusan Pancasila melalui materi yang disampaikan. Kesadaran akan pentingnya pebinaan nilai-nilai dan atau perilaku sopan santun itu dipahami oleh guru sebagai kegiatan insidental sehingga tidak perlu dimuat dalam silabus dan RPP. Hal ini terjadi juga dipengeruhi juga oleh kebiasaan guru membuat desain pembelajaran hanya memindahkan silabus yang sudah ada dalam buku kurikulum. Kemudian membuat RPPnya juga tidak melakukannya secara pribadi, artinya guru menyalin RPP yang sudah ada terlebih dahulu tanpa mengembangkannya lagi dengan penyesuaian-penyesuai kebutuhan kelas dan peserta didik yang tentunya berbeda setiap angkatan.

Dampak dari perumusan indikator dan tujuan yang tanpa melakukan analisis terhadap SK, KD ini adalah pada pengembangan materi. Artinya materi pembelajaran yang dirancang guru miskin nuatan nilai-nilai dan atau perilaku yang diharapkan oleh visi dan misi pembelajaran PKn. Seharusnya dalam materi itu wajib ada informasi-informasi tentang pengetahuan etika sopan santun yang dimasukan oleh guru, sehingga peserta didik melakukan sesuatu perilaku berdasarkan pengetahuan formal juga. Supaya suatu perlikaku itu dilakukan seseorang tentunya ia wajib tahu apa yang harus ia lakukan, mengapa harus melakukannya dan bagaimana pula cara melakukannya. Sebagai mana dikemukana oleh Likona, perilaku moral itu muncul didahului oleh pengetahuan tentang moral (moral knowing), dilanjutkan oleh ada perasan moral (moral filling), kemudia barulah akan dilaksanakan dan ditunjukkan dalam tindakan atau perilaku (moral acting). Artinya tanpa memiliki pengetahuan yang benar dan diinformasikan secara formal dalam materi, dikawatirkan peserta didik menganggap pendidikan berperilaku baik itu tidak penting, ia hanya pelajaran sambilan saja. Dan peneliti menganggap hal inilah yang menyebabkan mengapa pembelajaran PKn yang telah dipelajari peserta didik dari SD sampai PT tidak serta merta membekas menjadikan warga negara Indonesia berkepribadian sesuai dengan kandungan nilai-nilai Pancasila sebagai falsafah hidup, ideologi, dan dasar negara.

Pengembangan materi pembelajaran PKn;harusnya guru memperhatikan tiga aspek, yaitu formal content, informal content, dan respon siswa terhadap formal dan informal 
content (Winarno, 2013: 61). Formal conten bisa dikembangkan oleh guru dari banyak sumber yang dapat menunjang ketercapaian tujuan pembelajaran. Untuk memenuhi informal conten guru dalam memasukan informasi dari lingkungan peserta didik, baik lingkungan sosialbudaya maupun lingkungan alam. Lingkungan yang dipilih hendaknya lingkungan siswa seharihari. Selanjutnya, guru pun wajib melihat respon siswa terhadap dua perlakuan tersebut sebagai acuan dalam mengembangkan materi pembelajar berikutnya.

Penilaian perilaku sopansantun dalam RPP pun tidak dilakukan secara terprogram, dan ini berdampak tidak tepat dan kontinyunya guru membenahi perilaku-perilaku yang tidak pas yang ditunjukan oleh peserta didik karena program peniliannya lebih berat pada pengetahuan tentang ilmu kewarganegaraan, tidak pada perilaku yang wajib ditampilkan oleh peserta didik setelah ia memahami materi pembelajaran PKn

Pelakasanaanprogram pembelajaran masih mengunakan Kurikulu Tingkat Satua Pendidikan (KTSP). Sebelum memulai kegiatan belajar didahului dengan penyiapan fisik dan psikis peserta didik terlebih dahulu dengan cara guru dan peserta didik melakukan doa. Pada saat kegiatan pembelajaran, dominasi guru berkurang. Pelaksanaanpembelajaran tidak semuanya persis seperti dalam RPP, terutama dalam kegiatan pembelajaran.Nampakpeserta didik belajar secara aktif baik pada saat didkusi kelompok, pada kegiatan presentasi kelompok dan saat sesi tanya jawab.Selayaknya suatu pembelajaran harus mengaktifkan peserta didik, sebab belajar dengan memberikan pengalaman yang pas akan menjadikan pemebelajaran yang bermakna bagi peserta didik sejalan dengan pendapat Wahab (2011: 335) idealnya kegiatan pembelajaranhendaknya mendorong partisipasi peserta didik secara aktif, bersifat inkuiri dan mendorong untuk memecahkan masalah.

Guru memulai pembelajaran dengan melakukan aprsepsi yang cukup untuk memotivasi dan menggali latar belakang pengalaman dan pengetahuan peserta didik tentang pembelajaran yang akan mereka terima. Artinya guru sudah memahami bahwa ia wajib mencipta suasana yang kondusip pada awal pembelajaran agar kegiatan selanjutnya bisa berjalan efektif. Sebelum masuk ke kegiatan inti rupanya guru lupa menginformasikan tujuan yang akan mereka capai dari kegiatan itu. Sebenarnya informasi tujuan yang akan dicapai adalah hal yang esensi, sebab sesorang dalam melakukan sesuatu tentu saja harus meliki tujuan. Manakalah ia tidak paham apa tujuan yang akan dicapai terhadap apa yang ia lakukan, maka ditenggarai kegiatan itu akan tidak terfokus dan bisa berjalan tak tentu arah.

Pada kegiatan inti, guru mengawali dengan tahap-tahap eksplorasi, eleborasi, dan konfirmasi. Pada pelaksanaan ini guru memanfaatkan pendekatan pembelajaran kontruktivisyang divasiasikan dengan pendekatan inquri. Media yang digunakan cukup menarik karena menyajikan gambar-gambar yang sesuai dengan materi.Selain menggunakan media berupa gambar/benda, guru juga menjadikan diri sendiri sebagai media. Hal ini sangat tepat dilakukan terutama untuk menampilkan contoh perilaku, tata cara berperilaku, tindakan dan nilai-nilai yang baik bagi siswa.Memanfaatkan metode pembelajaran yang cukup bervariasi, yaitu tanya jawab, diskusi kelompok, ceramah, dan penugasan.

Kegiatan elaborasi juga dilakukan dengan memotivasi peserta didik untuk memunculkan gagasan baru baik lisan maupun tulisan, seperti mengenai hal yang belum diketahui siswa sebelumnya, memberikan pengalaman pada peserta didik untuk kooperatif dan kolaboratif, memberikan kesempatan menyajikan hasil kerja kelompok. Disela kegiatan, guru tak lupa membimbing dan mengingatkan peserta didik untuk belaku sopan santun dalam diskusi dan presentasi serta tanya jawab. Guru akan langsung menegur dan membenahi perilakuprilaku yang tidak mendukung pada kegiatan pemebelajaran, dan jika setelah itu peserta didik menunjukkan perilaku yang sesuai harapan guru akan memberikan pengutan berupa acungan jempol atau kata-kata pujian, seperti; bagus, 
pintar. Pada kegiatan konfirmasi, peserta didik bersama-sama mencari solusi yang tepat atas materi yang belum pas penyelesaiannya.

Di akhir pembelajaran, guru melakukan refleksi, terhadap kegiatan pembelajaran yang telah dijalani. Kegiatan penutup dilakukan tanya jawab mengenai materi yang telah disampaikan. Kegiatanakhir pembelajaran seharusnya dimaknai oleh guru, tidak hanya sebagai kegiatan menutup pembelajaran, tetapi juga sebagai kegiatan penilaian hasil belajar dan kegiatan tindak lanjut.Hendaknya pada saat guru membuat simpulan, tidak hanya terfokus pada materi pembelajaran atau aspek pengetahuan saja namun juga perlu memberi kesimpulan tentang bagaimana berperilaku yang baik, berperilaku sopan santun dalam kehidupan bersama, dalam mematuhi aturan, dan kesepakatan yang telah dibuat. Perilaku saling menghormati, toleransi seperti yang tersirat pada pembelajaran.

Evaluasi Pembinaan perilaku Sopan pada pembelajaran PKnmenggunakan penilaian kriteria, kadang-kadang dan belum nampak, teknik yang digunakan berupa pengamatan selama proses pembelajaran.Hasil pengamatan ini tidak dicatat secara langsung, artinya ketika guru mengamati perilaku siswa dia tidak mnggunakan cataatan, ternyata beliau hanya mencatat jika terjadi perilaku-perilaku ekstrim saja. Artinya guru tidak punya dokumen formal tentang perilaku siswa yang bertengkar dengan teman, mengejek dan lain sebagainya. Selayaknya guru memahami bahwa visi misi pembelajaran PKn adalah mengembangkan kepribadian peserta didik oleh karenanya evaluasi pada pembelajaran PKn yang paling utama adalah evaluasi afektif atau perilaku/sikap. Seperti yang dikemukakan oleh Winarno (2013: 223) bahwa pembelajaran PKn bercirikan penilaian kepribadian, namun guru tidak memiliki catatan khusus tentang penilaian sikap. Untuk itu, dapat dimaknai bahwa guru sebenarnya belum melaksanakan penilaian sikap dengan terprogram, sebenarnya evaluasi afektif atau sikap tidak dapat dipisahkan dengan evaluasi kognitif dan psikomotor. Penilaian perilaku/sikap melalui pengamatan saja tidaklah memadai untuk dijadikan acuan menilai prestasi dalam berperilaku. Tindak lanjut selalu dilakukan guru pada setiap pembelajaran dengan pemberian tugas rumah sesuai dengan materi. Meskipun demikian, tindak lanjut yang berhubungan dengan penanaman nilai-nilai Pancasila belum dilakukan guru.

Responsiswa terhadap muatan pembinaan sopan santun dalam pembelajaran PKn dapat dikatakan menerima pesan-pesan yang disarankan oleh guru. Penerimaan ini terlihat dari mereka mau melakukan perbuatan yang menunjukkan perilaku sopan santun pada saat pembelajaran di kelas, maupun saat istirahan di luar kelas.Perilaku ini dilaksanakan peserta didik dikarenakan guru selalu memotivasi mereka untuk menjukkan perilaku tersebut. Disamping itu pun guru memberikan contoh nyata bagaimana perilaku sopan santu yang dia tunjukkan pada saat di kelas maupun di luar kelas. Sebagaimana diketahui bahwa individu pada usia sekolah dasar itu sangat mudah meniru segala perilaku yang dia lihat dan dia rasakan nyaman untuk melakukannya. Maka dengan demikian contoh nyata yang ditunjukkan sosok yang ia hormati akan ditiru untuk dilakukannya. Melalui peniruan inilah individu mengadopsi nilai-nilai, moral atau perilaku untuk diinternalisasikannya dalam sistem kepribadiannya.

Disamping pemberian contoh dan teladan, motivasi dan pemberian pengalaman untuk melakukan suatu tinadakan yang diharapkan guru pada peserta didik, juga diberikan penguatan terhadap perilaku yang dikehendaki yang ditunjukkan oleh peserta didik.Seperti memberikan pujian serta penghargaan pada peserta didik. Ini semua akan memperkuat motivasi peserta didik untuk mengulangi perilaku yang dipujikan itu secara berulang-ulang sehingga lama kelaman perilaku itu mempersonalisasi pada peserta didik. Djuwita (2005) mengungkapkan bahwa pada awalnya anak didik hanya melihat memperhatikan perilaku perilaku orang-orang disekitarnya, selanjutnya dia akan mencobakan perilaku tersebut. Manakala dengan melakukan perilaku itu dia diterima oleh lingkungannya, artinya dia tidak mendapat celaan dan hukuman, maka ia 
akan melakukannya secara terus-menerus inilah yang disebut sebagai proses imitasi, selanjutnya dia tersugesti untuk berbuat itu karena mendapat pujian. Menurut Lawren Kolberg, ini disebut tahap perkembangan moral pre-konvensional. Pendidik selayaknya mampu menghadirkan iklim kelas yang akan membuat peserta didik mengalami proses pengadopsian nilai, moral sehingga peserta didik menjalani tahap-tahap perkembangan berperilaku (moral) baik serta menyenangkan tanpa merasa tertekan dan intimidasi dari kekuasaan guru. Jika pendidik memberikan stimulus yang positif dan menyenangkan, maka siswa pun akan merespon stimulus itu dengan positif pula. Melalui stimulus berupa cerita-cerita tentang kegiatan-kegiatan sehari-hari yang dialami peserta didik tetang manfaat berperilaku sopan santun serta keburukan jika tidak berperilaku sopan santun akan terjadi klarifikasi nilai (kejelasan nilai) mana yang akan dia adopsi dalam diri.

\section{SIMPULAN}

Secara umum dapat disimpulakan bahwa guru telah berusaha membinakan perilaku sopan santu pada peserta didk melalui pembelajaran PKn meskipun belum terpola dan terprogram secara formal. Simpulan secara rinci sebagai berikut:

1. Desain pembelajaranPKn yang dibuat oleh guru menggunakan silabus BNSP. Guru tidak menganalisis SK dan KD terlebih dahulu. RPP yang dipakai bersumber dari buku pegangan atau panduan gurutanpa analisis misi nilai dan perilaku yang diharapkan dari SK dan KD, sehingga indikator yang dirumuskan tidak terdapat pembinaan etika sopan santun yang akan dilakukan. Materi tidak dikembangkan secara kontekstual

2. Ketika pembelajaran dilaksanakan guru telah melakukan pembinaan perilaku sopan santun. Gurutelah mampu memotivasi peserta didik untuk berperilaku sopan santun

3. Evaluasi hasil pembinaan perilaku sopan santun belum terprogram secara formal.
Evaluasi masih dominaan pada evaluasi aspek kognitif.

4. Peserta didik telah merespon secara positif dan aktif terhadap membinaan perilaku sopan santun .

\section{SARAN}

1. Hendaknya guru sebelum mendesain pembelajaran terlebih dahulu melakukan anlisis kurikulum, sehingga dapat memaknai nilai-nilai dan perilaku apa yang diharapkan melalui materi PKn yang akan dikuasai peserta didik. Oleh karena itu silabus dan RPP menjadi miliki pribadi guru dan pas untuk peserta didik di kelasnya karena dikembangkan sendiri, berdasarkan pertimbangan terhadap tahap perkembangan dan kebutuhan peserta didik.

2. Akan lebih baik jika dalam pelaksanaan pembelajaran itu, setelah pesrta didik diberi pengalaman tentang perilaku sopan santun, sejenak dilakukan permaian peran tentang perilaku sopan santun dengan skenario cerita yang menarik dan dipersiapakn terlebih dahulu dalam desain pembelajaran.

3. Perilaku yang dibinakan dalam pembelajaran PKn wajib dilakukan penilaian keberhasilan peserta didik berperilaku sesuai harapan, untuk itu selayaknya guru memliki catatan lengkap tentang perkembangan perilaku mereka masing-masing. Guru menyiapkan catatan resmi (anadektol record) dan atau portopolio untuk setiap peserta didik.

\section{DAFTAR PUSTAKA}

Anitah. Sri. W.,dkk. 2008. Strategi Pembelajaran di SD. Jakarta:Universitas Terbuka.

Antoro. Dwi Sunu. 2010. Pembudayaan Sikap Sopan Santun di Rumah dan Di Sekolah. Jurnal Pendidikan. Yogyakarta: Universitas Terbuka.

Daryanto., dkk. 2013. Implementasi Pendidikan Karakter di Sekolah. Jakarta: Kencana 
Puspa Djuwita

Fathurrohman \& Wuryandari, Wuri. 2011. Pembelajaran PKn di Sekolah Dasar. Bantul: Nuha Litera.

Majid, Abdul.2009. Perencanaan Pembelajaran Mengembangkan Standar Kompetensi Guru. Bandung: PT. Remaja Rosdakarya

Muhajir. 2010. Indahnya memiliki sopan santun. Jurnal ilmu pendidikan.

Ratnasari. Deni. 2013. Penanaman sikap sopan santun sebagai pendidikan moral kepada siswa melalui tata tertib sekolah. Jurnal pendidikan. Surabaya:UNESA

Rusmini. 2012. Peran guru dalam menanamkan karakter sopan santun siswa. Jurnal pendidikan. Banjar masin: Universitas Lambung Mangkurat

Sapriya. 2012. Pembelajaran Pendidikan Kewarganegaraan. Jakarta: Direktorat Jenderal Pendidikan Islam Kementerian Agama Republik indonesia

Sugiyono. 2011. Metode Penelitian Kuantitatif, Kualitatif, dan $R \& D$. Bandung: Alfabeta

Sumarsono., dkk. 2008. Pendidikan Kewarganegaraan. Penerbit: PT. Gramedia Pustaka Utama Jakarta.

Susanto. Ahmad. 2013. Pendidikan Kewarganegaraan. Jakarta : PT Gramedia Puataka Utama.

Wahab. Abdul Aziz., dkk. 2011. Teori \& Landasan Pendidikan Kewarganegaraan. Bandung: Alfabet

Winataputra, U.S. 2002. Strategi Belajar Mengajar. Jakarta: Universitas Terbuka

Winataputra, U.S. 2009. Pembelajaran PKn di $S D$. Jakarta: Universitas Terbuka

Winarno. 2013. Pembelajaran Pendidikan PKn. Jakarta: Bumi Aksara 